$$
\begin{aligned}
& \text { 凝結調整剂を添加したスラッジ水を練混ぜ水に用いた } \\
& \text { コンクリートの諸特性 }
\end{aligned}
$$

\title{
Some Properties of Concrete Containing Sludge Water with Setting Retarder
}

\author{
by
}

\author{
Junji Nakamoto ${ }^{*}$, Kazuo Togawa ${ }^{*}$, Yoshitaka Mrtsurwa ${ }^{*}$ and Toshiyuki Tan ${ }^{*}$
}

\begin{abstract}
Authors have been studying for several years as for the effective utilization of sludge water produced in ready mixed concrete plants due to washing of a mixer, agitating truck dram etc. Nowadays, JIS A 5308 permits the usage under 3 percent as solids of sludge for the unit content of cement of new concrete. Recently, it is strongly requested to re-use a further large quantity of sludge water, in order to achieve the zero-emission. Sludge water consists of cement, fine particles of aggregate and water. All materials are one of the constituents of concrete. This study, in order to utilize the larger quantity of sludge water than that now allowed, is to verify the properties of concretes containing sludge which were designed for the identical slump and compressive strength to comparative concrete. From the results of this study, it became clear that as for the sludge concrete containing sludge within the range of 3-15\%, there was no problem about the properties of fresh and hardened concrete, that is, slump, bleeding, compressive strength, drying shrinkage, carbonation depth and freezing and showing resistance, etc. In other words, within the range of $15 \%$ of sludge solid content, the concrete containing sludge water with setting retarder could obtain good performance as same as comparative concrete. It was also confirmed that the bulk volume of coarse aggregate was available for the design method of concrete mixture.
\end{abstract}

Key words : Zero-emission, In-plant recycle, Concrete sludge, Setting retarder, Mix design, Properties of fresh concrete, Properties of hardened concrete, Bulk volume of coarse aggregate

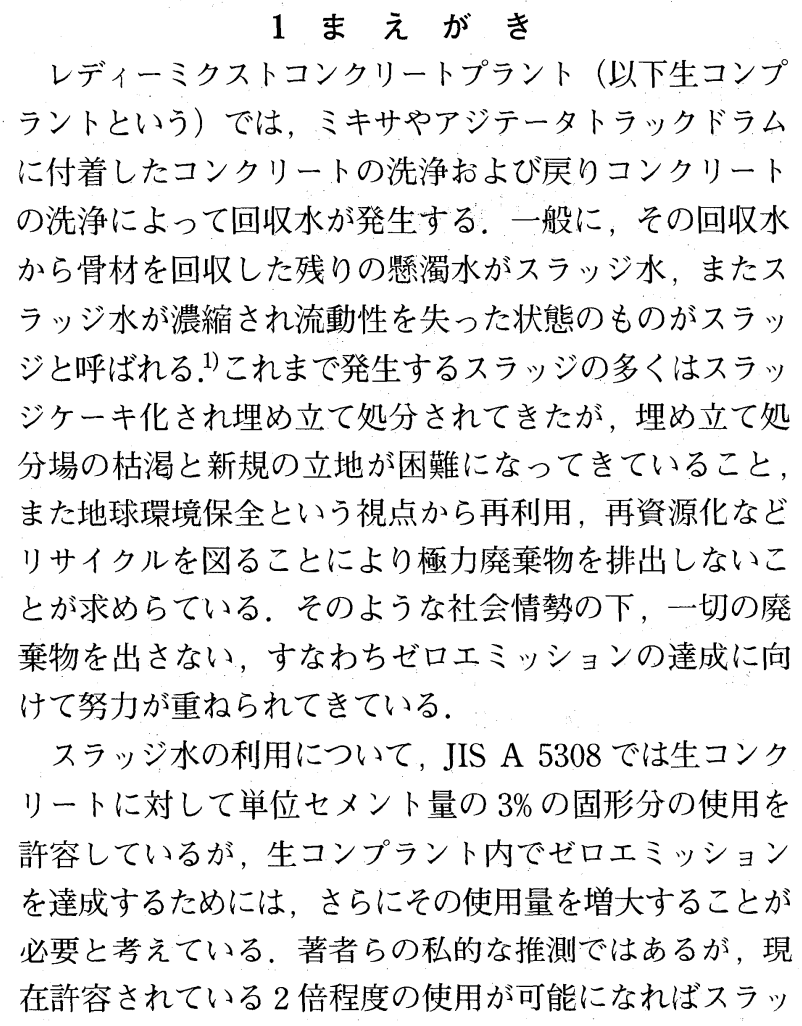


は，フレッシュコンクリートについてはスランプロスなら びにブリーディング特性，硬化コンクリートについては 圧縮強度, 乾燥収縮ひずみ, 中性化深さおよび凍結融解 抵抗性である。

\section{$2 \cdot 1$ 使用材料}

\section{2 実 験 概 要}

セメントは，普通ポルトランドセメント（密度 $3.16 \mathrm{~g} /$ $\mathrm{cm}^{3}$ ) を使用した。細骨材は徳島県那賀川産の川砂（密 度 $2.61 \mathrm{~g} / \mathrm{cm}^{3}$, 粗粒率 3.01 , 吸水率 $1.84 \%$ ， 粗骨材は赤 穂市西有年産の流紋岩質溶結凝死岩砕石（密度 2.63 $\mathrm{g} / \mathrm{cm}^{3}$ ，粗粒率 6.57 ，吸水率 $0.80 \%$ ，最大寸法 $20 \mathrm{~mm}$ ) を用いた。混和剤は $\mathrm{AE}$ 減水剂（リグニンスルホン酸化 合物およびポリオール複合体）および $\mathrm{AE}$ 助剤（変形ア ルキルカルボン酸化合物系陰イオン界面活性剤）を使用 した。 また，使用した凝結調整剤の主成分はアルキルア ミノホスホン酸系である

\section{$\mathbf{2} \cdot \mathbf{2}$ スラッジの配合}

スラッジ水は，前述の品質やスラッジ水に占める固形 分の濃度（以下，スラッジ水の濃度と呼ぶ）が一定に管 理できるように実験室内において作成した。また，スラッ ジ水のかく找は, 生コンプラントのスラッジ水処理設備 をモデル化したかく拌機を作成して行った。近隣の生コ ンプラントで発生するスラッジ水の調査を行ったところ， スラッジ水に占める固形分の割合は約 15\%，固形分に占 める骨材細粒分の割合は約 $20 \%$ であった。 なお，スラッ ジ固形分に含まれる骨材細粒分の最大粒径は $0.15 \mathrm{~mm}$ 程 度であった。

本研究では, Table I に示すようにスラッジ水は実際 の生コンプラントで発生するスラッジ水に近い配合のも のを作成した．スラッジ水は，まずセメント，骨材細粒 分および水（水セメント比 $60 \%$ 相当分）を混入して練り 混ぜた。そして, 練混ぜ時から 3 時間経過後に水の質量 割合が $85 \%$ になるようにスラッジ水に残りの水を加えて 作製した。 また，スラッジ水への凝結調整剤の添加も練 混ぜ時から 3 時間後に行った。ここで 3 時間としたのは 生コン製造後ミキサー車が生コンプラントを出発して戻う てくるまでの時間を 3 時間と想定したことによっている. なお，スラッジ水は作製時から試験に供するまで $20^{\circ} \mathrm{C} の$ 環境下でスターラーにより継続してかく拌した.

\section{$2 \cdot 3$ 凝結調整剤の添加率と実験計画}

スラッジ水中のセメント粒子の水和の進行を管理する ことができればスラッジ水の品質の安定化につながると 考えられる：そしてスラッジ水の品質が安定化すれば委 員会報告 ${ }^{5)}$ にあるようにスラッジ固形分の使用量の増加 が期待できるものと考えられる。ここではスラッジ水中

Table I . Mix proportion of sludge.

\begin{tabular}{|c|c|c|c|}
\hline $\begin{array}{c}\text { Cement } \\
(\text { mass\%) }\end{array}$ & $\begin{array}{c}\text { Fine sand* } \\
(\text { mass\%) }\end{array}$ & $\begin{array}{c}\text { Water } \\
\text { (mass\%) }\end{array}$ & $\begin{array}{c}\text { Setting } \\
\text { Retarder } \\
(\text { Cement } \times \%)\end{array}$ \\
\hline 12 & 3 & 85 & 2 \\
\hline
\end{tabular}

のセメントの水和の進行によるスラッジの固化を防ぐ目 的で凝結調整㓮を使用した。 スラッジ水中のセメントの 水和の進行度合いは粉末 $\mathrm{X}$ 線回折試験によって水酸化力 ルシウムの生成の有無を確認することと強熱減量試験に より検証した。

その結果，環境温度 $20^{\circ} \mathrm{C}$ 場合，スラッジ水中のセメ ント量 (C)，に対して凝結調整剤を $2 \%$ 添加することによ り練混ぜ後材齢 72 時間まではセメントの水和を抑制し てスラッジの固化を防止できることが明らかとなった。 そのため本実験では，凝結調整剂の使用量は $\mathrm{C} \times 0.02$ の 一定 ${ }^{6)}$ とした。

使用スラッジ水の材齢は，これまでの研究 2), 3)のとお り 1 日と 3 日の 2 段階を考えた。なお，材齢 1 日のスラッ ジ水については凝結調整剤は添加せずに，材齢 3 日のス ラッジ水についてのみ凝結調整剤を添加することにした。 コンクリートへのスラッジ固形分率については，これま での研究で $9 \%$ までの使用が可能と判断されたがさらに 多量使用の可能性を検討するために，コンクリートの単 位セメント量に対して，スラッジ固形分率で 3,9 および $15 \%$ の 3 段階を計画した．実験計画を Table II に示す。

\section{$2 \cdot 4$ コンクリートの各種試験方法}

フレッシュコンクリートのスランプおよびブリーディン グは, JIS A 1101 「コンリートのスランプ試験方法」, JIS A 1123「コ.ンクリートのブリーディング試験方法」 により行った。また，硬化コンクリートの圧縮強度試験， 乾燥収縮試験および凍結融解試験については，JIS A 1108 「ンクリートの圧縮強度試験方法」, JIS A 1129 「モルタルおよびコンクリートの長さ変化試験方法（コン タクトゲージ法)」およびJIS A 1148 「コンクリートの凍 結融解試験方法（A 法）」に準じた。中性化促進試験は, 炭酸ガス濃度 $15 \%$, 温度 $35^{\circ} \mathrm{C}$, 相対湿度 $60 \%$ の環境下 で行った。なお, コンクリートの練混ぜ時, 養生時およ び各種試験時の環境温度は中性化促進試験を除いてすべ

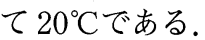

\section{3 結 果 の考 察}

\section{$3 \cdot 1$ コンクリートの配合設計方法}

本研究では，通常の土木用のコンクリートを想定して， スランプ $8 \pm 1 \mathrm{~cm}$ ，空気量 $4.5 \pm 1 \%$ を計画した。 また，本 実験ではコンクリートの配合設計は，単位粗骨材容積法 により行った。 同一のワーカビリティーを得るための粗骨 材かさ容積は，コンクリート標準示方書「施工編」7)にも 示されているように細骨材の粗粒率と線形関係にある. スラッジ水を添加した場合，スラッジは $0.15 \mathrm{~mm}$ 以下の 微粒分なのでそれを細骨材の一部とみなすと細骨材の粗

Table II . Test program.

\begin{tabular}{|c|cc|}
\hline Factor & \multicolumn{3}{|c|}{ Level } \\
\hline Sludge content (\%) & $0,3, \quad 9, \quad 15$ \\
\hline Age of sludge (day) & 1,3 \\
\hline $\begin{array}{c}\text { Setting retarder content } \\
\text { (Cement } \times \%)\end{array}$ & $0, \quad 2$ \\
\hline
\end{tabular}


粒率が小さくなることになる，すなわち，スラッジ固形 分率の増加によって, 細骨材の粗粒率は減少することか ら，粗骨材かさ容積は増加することになる。

基本的に使用する骨材の違いによって，粗骨材かさ容 積は変化するがここではスラッジ水を添加しない基準コ ンクリートについて 0.66 を選定した。 また, スラッジ固 形分率が $3 \%$ 程度（JIS の許容範囲内）であれば大きな影 響はないと判断し，スラッジ固形分率 $3 \%$ の場合の粗骨 材かさ容積は基準コンクリートの場合と同じ 0.66 とし た。な打，スラッジ固形分率の増加による粗骨材かさ容 積の増加率については，コンクリートがワーカブルでプ ラスティックな状態にあることを目視で判断して決定し た。本実験では，スラッジ固形分率 $6 \%$ の増加で粗骨材 かさ容積は 0.02 増加する結果となった。

配合設計手順としては，それぞれのスラッジ固形分率 における粗骨材かさ容積を定めた後, 基準コンクリート と同一スランプが得られる単位水量を選定した，スラッ 沙水に凝結調整剂を添加した場合, 減水効果があること から単位水量 (W) は若干減少した。兄して, 基準コン クリートの材齢 28 日圧縮強度と同一強度を得る水セメン 卜比を定めるための $\mathrm{C} / \mathrm{W}$ 一強度関係を得るために, ここ では基準コンクリートの水セメント比 (57.9\%) を中心にし てW/C を $5 \%$ 増減させた配合を計画した。なお，スラッ ジ固形分率が一定の場合では, コンクリートの単位水量 扔よび粗骨材かさ容積も一定とした。

Fig. 1 は，スラッジ水混入コンクリートについて，材齢 28 日の圧縮強度とセメント水比 (C/W) の関係をプロッ トしたものである。な报，図中の破線は，基準コンクリー 卜の圧縮強度值を示している，同図に示すようにスラッ ジ水混入コンクリートについても通常のコンクリートと 同様に圧縮強度とセメント水比 $(\mathrm{C} / \mathrm{W})$ の間には線形関 係が成立すると考えてよい。

したがって，各スラッジ水混入コンクリートについて， 基準コンクリートと同等の圧縮強度を得るための水セメ ント比は回帰直線関係から内挿法により求めた。な打, 15\%SRについては, 強度改善効果が大きかったため, 外 挿により求めることとなった。 その結果，Table IIIに示 すように本配合が定まった.8)

Table III より，凝結調整剤を添加したスラッジ水を用 いた場合，スラッジ固形分率が高くなるにしたがって， 同一スランプを得るための単位水量は低減し，また同一 強度を得るための水セメント比は高くなることがわかる.

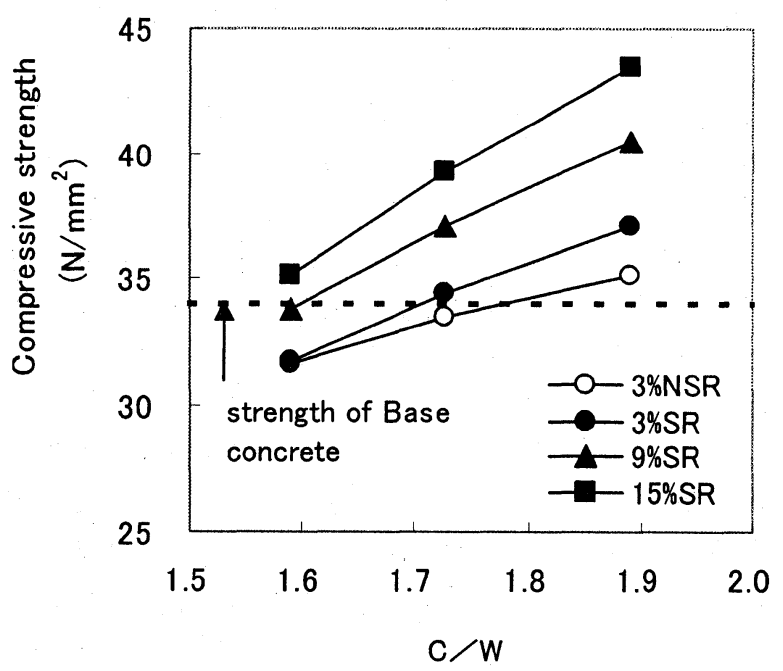

Fig. 1. Relationship between compressive strength and nominal $\mathrm{C} / \mathrm{W}$.

\section{$3 \cdot 2$ スランプの経時変化}

Fig. 2 はスランプおよび材齢 28 日の圧縮強度を同一 にしたコンクリートのスランプの経時変化を示している. なお，前述したように材齢 1 日のスラッジ水については 凝結調整郕は無添加であり，材齢 3 日のスラッジ水には 凝結調整剂を所定量添加している。

本研究では，いずれのコンクリートについても時間経 過に伴うスランプの変化はほぼ同程度であり, 基準コン クリートとも違いは認められない。

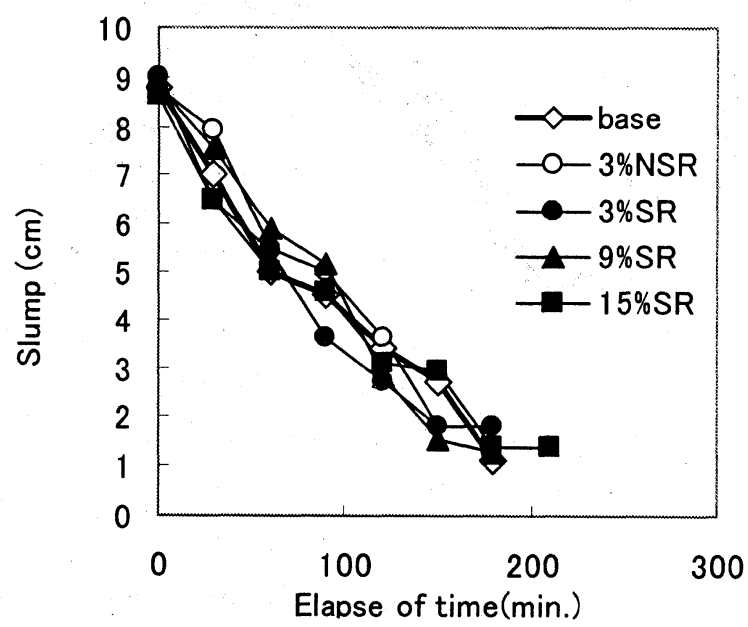

Fig. 2. Relationship between slump and time after completion of mixing.

Table III. Mix proportion of concrete.

\begin{tabular}{|c|c|c|c|c|c|c|c|c|c|c|c|c|}
\hline Notation & $\begin{array}{c}\text { Sludge } \\
\text { Content } \\
\end{array}$ & $\begin{array}{c}\text { Setting } \\
\text { Retarder } \\
(\%)\end{array}$ & $\begin{array}{c}\text { Slump } \\
(\mathrm{cm})\end{array}$ & $\begin{array}{l}\mathrm{W} / \mathrm{C} \\
(\%)\end{array}$ & $\begin{array}{c}\text { Air } \\
(\%)\end{array}$ & $\begin{array}{l}\mathrm{s} / \mathrm{a} \\
(\%)\end{array}$ & $\mathrm{W}$ & $\mathrm{C}$ & $\mathrm{S}$ & $\mathrm{G}$ & $\begin{array}{c}\mathrm{AE} \text { water } \\
\text { reducer }\end{array}$ & $\begin{array}{c}\text { AE agent } \\
* *\end{array}$ \\
\hline base & 0 & 0 & $8 \pm 1$ & 57.9 & $4.5 \pm 1$ & 45.8 & 162 & 280 & 843 & 1003 & 2.80 & 1.511 \\
\hline $3 \% \mathrm{NSR}$ & 3 & 0 & $8 \pm 1$ & 56.2 & $4.5 \pm 1$ & 45.7 & 162 & 288 & 836 & 1003 & 2.88 & 1.730 \\
\hline $3 \% \mathrm{SR}$ & 3 & 2 & $8 \pm 1$ & 58.0 & $4.5 \pm 1$ & 46.3 & 158 & 272 & 860 & 1003 & 2.72 & 1.634 \\
\hline $9 \% \mathrm{SR}$ & 9 & 2 & $8 \pm 1$ & 62.5 & $4.5 \pm 1$ & 45.5 & 155 & 248 & 857 & 1034 & 2.48 & 1.340 \\
\hline $15 \% \mathrm{SR}$ & 15 & 2 & $8 \pm 1$ & 64.2 & $4.5 \pm 1$ & 44.1 & 155 & 241 & 833 & 1064 & 2.41 & 1.303 \\
\hline
\end{tabular}

$* 4$ dilution $\quad * * 100$ dilution 
ちなみにスランプロスはセメント粒子の水和の進行に より，自由水で占められていた部分が水和物により置換 される過程で水和物の凝集が起こり，次第に流動性が失 われていくものであり，水和物の生成量と水隙の関係で 定まる。スランプロスについて，上述したような結果に なった理由として，本研究では Table IIIより凝結調整乳 を添加したスラッジ水を用いた場合には，同一スランプ および同一強度を得る単位水量および単位セメント量は 減少することがわかる。一方，後述の Fig. 4 に示される ようにいずれのコンクリートについても補正 C/W はほ ぼ同程度である。したがって，水和が同程度であれば疑 結調整郕を用いて単位水量が少ない場合の方がスランプ ロスは大きくなるが，反面，凝結調整剤は水和を遅延す る働きをするため，それらが相殺されて凝結調整剈を用 いない基準コンクリートと同程度のスランプロスとなっ たものと考えている。

\section{$3 \cdot 3$ ブリーディング特性}

Fig. 3.は，各種コンクリートのブリーディング率の経時 変化を示している。また, Fig. 4 は, 基準コンクリートと 同じ強度を得るための $\mathrm{C} / \mathrm{W}$ を示している。な捛同閁で は，Fig.1から求めた $\mathrm{C} / \mathrm{W}$ を見かけの $\mathrm{C} / \mathrm{W}$ (nominal

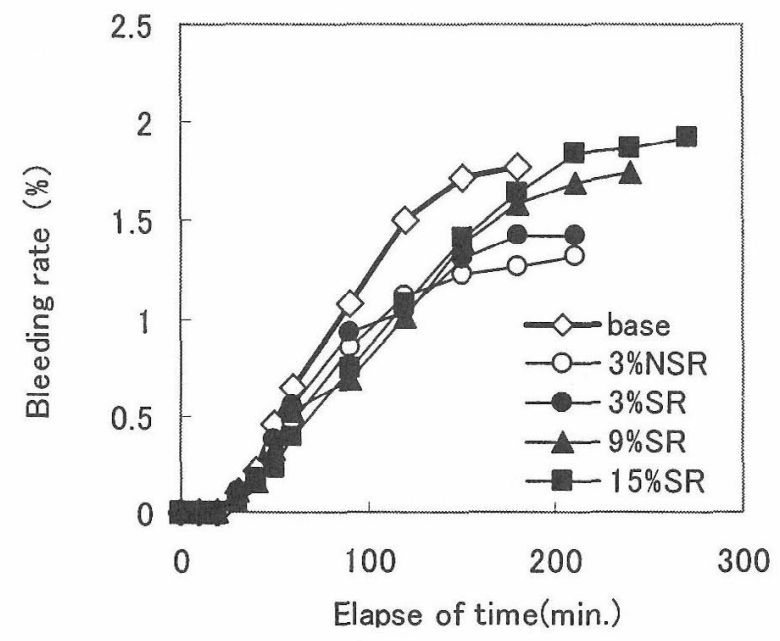

Fig. 3. Results of bleeding rete of concretes.

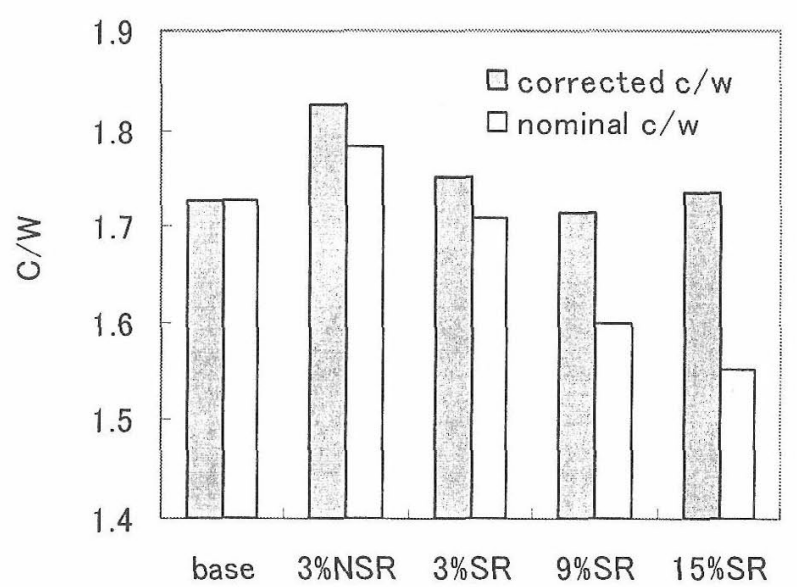

Fig. 4. $\mathrm{C} / \mathrm{W}$ to obtain strength identical to the comparative concrete.
$\mathrm{C} / \mathrm{W})$ ，スラッジ水中のセメント粒子を単位セメント量の 一部として計算したセメント水比を補正 $\mathrm{C} / \mathrm{W}$ (corrected C/W) と定義している。

コンクリートのブリーディング率は, 凝結調整剤添加, 無添加，またスラッジ添加率にかかわらず試験開始後か ら時間経過とともに増加する。そして凝結調整剂無添加 の場合はブリーディングの終了が早くなるといえる。凝 結調整剤添加の場合は, 無添加の場合と比較してブリー ディングの終了が遅く，その結果ブリーディング率は大 きくなっている。

これまで，基準コンクリートにスラッジを外割添加し たスラッジ水混入コンクリートについては，凝結調整剤 無添加のスラッジ水の場合, 最終ブリーディング率は, スラッジ固形分率が増加すれば減少し，凝結調整剬を添 加したスラッジ水を用いた場合，ブリーディング率は凝 結調整凰無添加スラッジ水の場合よりも多くなることを 明らかにしてきた。2) 3)しかし，本研究では，Fig. 3 に示 すように凝結調整剤を添加したスラッジ水を $9 \%$ および 15\% 添加したコンクリートは最終ブリーディング率が基 準コンクリートと同程度になった。これは，単位水量が 少なくなったことと, Fig. 4 に示すように見かけの C/W は小さくなるが補正 C/W はほぼ同程度になることによ ると考えられる。孚

\section{$3 \cdot 4$ 圧縮強度}

Fig. 5 は，各種コンタリートの材齢 7 日，28日抢よび 91 口の圧縮強度試験結果を示している。

材齢 28 日の目標圧縮強度は $34 \mathrm{~N} / \mathrm{mm}^{2}$ であるが基準 ンタリートならびに凝結調整剤を用いないスラッジ固形 分率 $3 \%$ のコンリート (3\%NSR) については，若干日標 強度に至らなかった。このことは，最初に設定した強 度一 $\mathrm{C} / \mathrm{W}$ 推定直線の若干の不正確さによるものと考え られる。また，いずれの配合についても，材齢の経過に 伴う強度の増進の程度は通常のコンクリートと同様と考 えられる。ただ，3\%NSRについては強度増進の程度は若 干低い結果となった。これは，Fig. 4に示しているよう に，凝結調整荗を用いないスラッジ水を添加した場合，

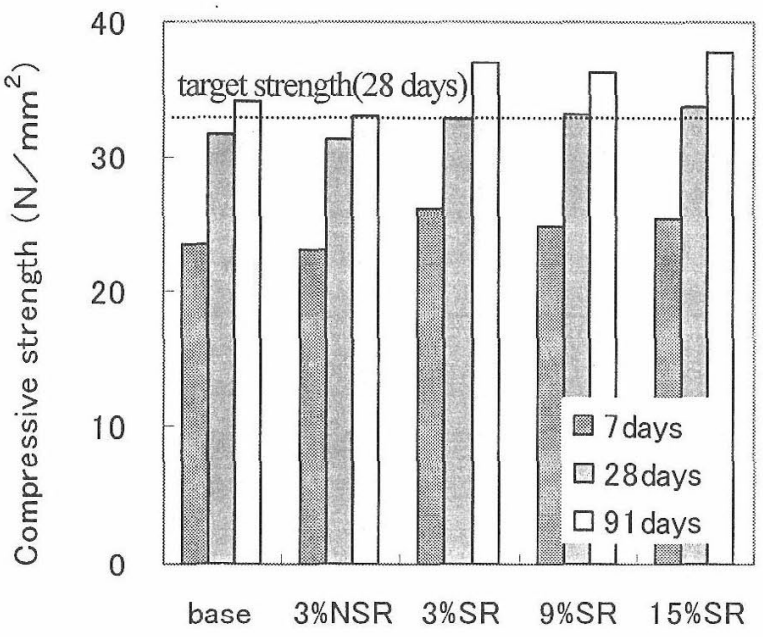

Fig. 5. Compressive strength of concretes. 
同一強度を得るための $\mathrm{C} / \mathrm{W}$ が大きくなることから，ス ラッジ水中のセメント粒子が強度増進に悪影響を与えて いることが危惧される。

以上のことから，凝結調整剤を用いたスラッジ水の場 合，スラッジ固形分率が 15\%の範囲内では，いずれのコ ンクリートについても, 圧縮強度の面からは問題はない と考えられる。

\section{$3 \cdot 5$ 乾燥収縮ひずみ}

Fig. 6 は, 材齢 28 日まで $20^{\circ} \mathrm{C}$ で水中養生し, 以後温 度 $20^{\circ} \mathrm{C}$, 湿度 $60 \%$ で気中養生した場合の各種コンクリー トの乾燥収縮ひずみと材齢との関係を示している.

全てのコンクリートについて乾燥材齢初期においては 急激に収縮するが材齢の経過とともに増加割合が小さく なる。いずれのスラッジ水を用いたコンクリートの乾燥 収縮についても，基準コンクリートと比較して同等か若 干小さくなる結果となった。これは，スラッジ固形分率 が大きい場合, 見かけの W/C は大きくなるので, 乾燥 収縮ひずみも大きくなることが予想されるが，Fig. 4 に 示したように補正 $\mathrm{C} / \mathrm{W}$ 比はほとんど同じであること，ま た Fig. 5 に示したように圧縮強度は若干大きいこと，単 位水量が少ないこと，さらにスラッジ水中のセメント粒 子を単位セメントの一部と考えた場合でも単位セメント 量は若干少ないことから, 乾燥収縮ひずみは小さくなっ たものと考えている.

したがって，スランプと材齢 28 日の圧縮強度を同じ になるように配合設計した場合，スラッジ水の使用は乾 燥収縮の面からは何ら問題ないようである.

Fig. 7 は, 水中養生終了時点を基準として材齢 355 日 までの乾燥収縮ひずみ測定用供試体の質量减少率を示し ている．スラッジ固形分率が多いコンクリートの方が質 量減少量は少ない. こ机はスラッジ水中のセメント粒子 が結合材として有効に働き, また実質的な水セメント比 が若干小さくなっていることから，コンクリートがより 密実化していることを示しているものと考えられる.

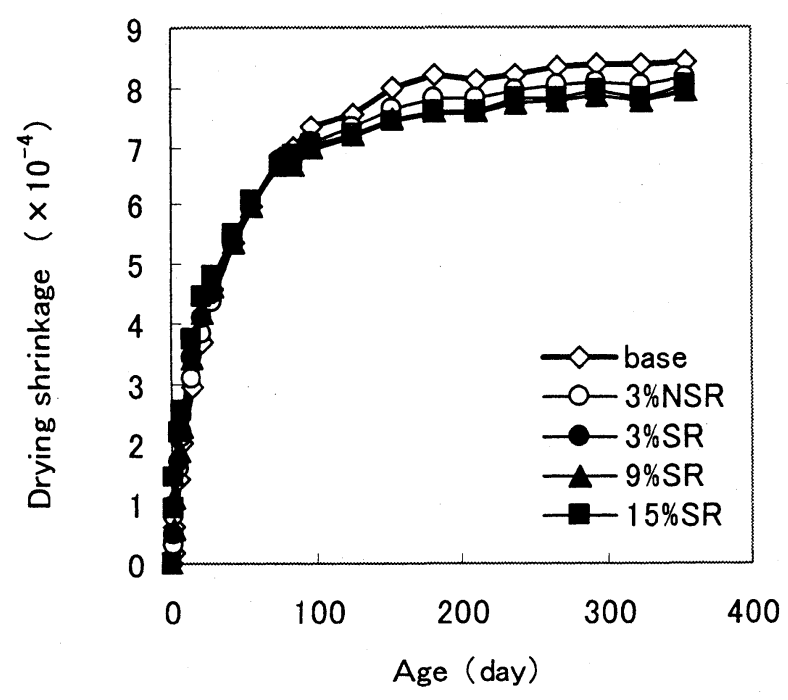

Fig. 6. Drying shrinkage of concretes.

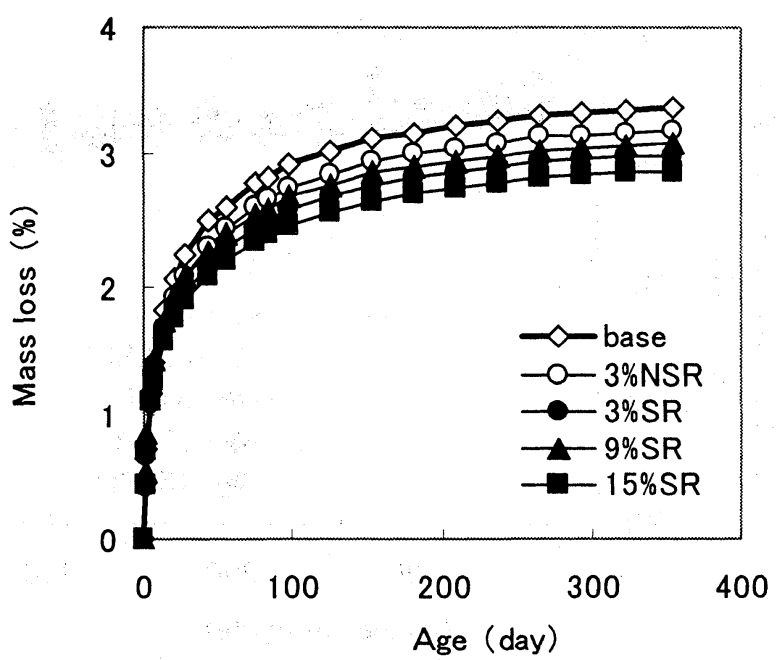

Fig. 7. Mass loss of concretes.

\section{$3 \cdot 6$ 中性化深さ}

Fig. 8 は，材齢 28 日まで水中養生した後，2週間気 中乾燥させたコンクリート供試体を促進中性化させた中 性化深さと促進中性化期間との関係を示している。中性 化深さは, 切断面にフェノールフタレイン $1 \%$ エタノー ル溶液を噴霧し, 赤変しない部分の平均深さで表してい る.図より，中性化深さは $15 \% \mathrm{SR}$ が最も小さい. また， いずれのコンクリートについても大きな違いは認められ ない.

スランプと材齢 28 日の圧縮強度を同じになるように 配合設計したスラッジ水混入コンクリートについては， 中性化に関して普通のコンクリートと同等と考えてよい. なお，本実験結果については，通常の $\sqrt{\mathrm{t}}$ 則よりは直線に 近い関係となった。

\section{$3 \cdot 7$ 凍結融解抵抗性}

Fig. 9 は, 各種コンクリートの耐凍結融解抵抗性試験 (A 法) の結果を示している.

いずれのコンクリートについても耐久性指数が 95 以上 と十分に凍結融解抵抗性を有することが確認された。 ラッジ水混入コンクリートの凍結融解抵抗性は, スラッ ジ水無混入のコンクリートの耐凍結融解抵抗性と異なる

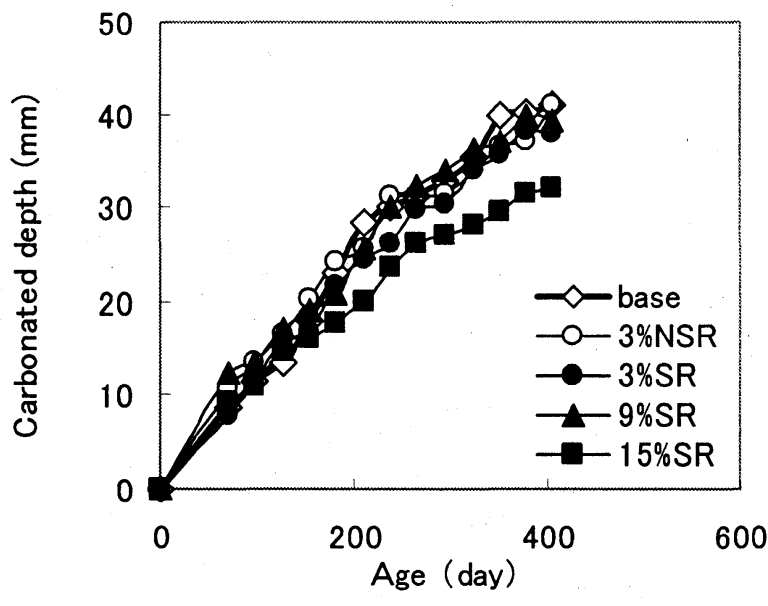

Fig. 8. Relationship between carbonated depth and age. 


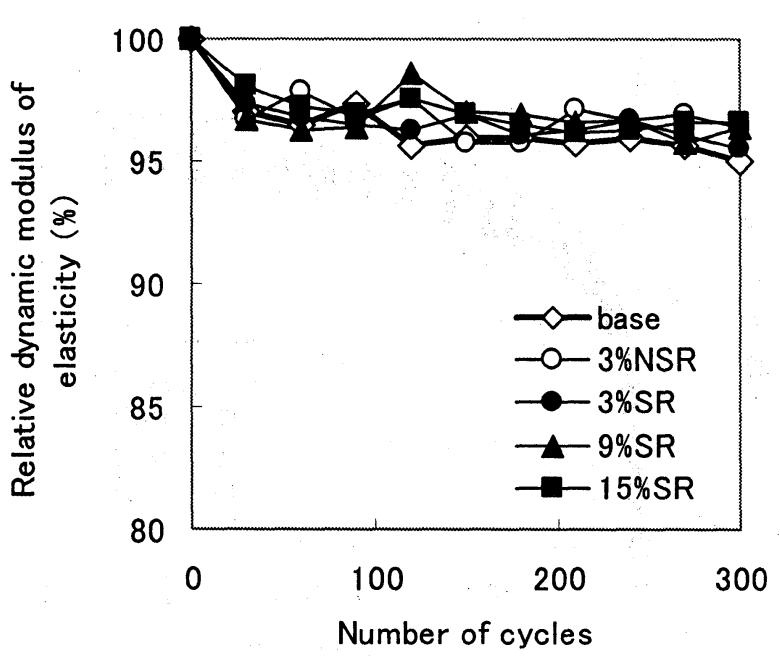

Fig. 9. Results of freezing and thawing resistance of concretes.

ことはなく，耐凍結融解抵抗性の面から，凝結調整凨を 添加して安定化させたスラッジ水を固形分率 $15 \%$ まで用 いることは問題ないと考えてよい.

\section{4 結 論}

本研究は, スラッジ水の多量有効利用を図る目的で, 生コンプラントから排出されるスラッジ水と同等な成分 を有する人工的に配合されたスラッジ水に凝結調整剤を 添加して安定化したスラッジ水を用いたコンクリートに ついて，スラッジ水無混入の基準コンクリートと同等の 特性（ここでは，スランプならびに材齢 28 日の圧縮強 度）を有するスラッジ水混入コンクリートを配合設計し， それらスラッジ水混入コンクリートの諸特性を実験的に 検討したものである.

本実験の範囲内で次のことがいえる.

(1) 本研究では，スラッジ水混入コンクリートの配合 設計方法に関して, 単位粗骨材容積法を用いることを試
みたが，単位粗骨材容積法は有用であることが確かめら れた。

(2) スラッジ水混入コンクリートのフレッシュコンク リートのスランプロスはスラッジ固形分率が違ってもほ ぼ同程度であり, 基準コンクリートとの違いは認められ ない，また，ブリーディング率も基準コンクリートと同 程度か若干低い結果となった。

（3） スラッジ水混入コンクリートの硬化コンクリート の諸特性について, 材齢の経過に伴う強度の增進の程度 は基準コンクリートと同様であった。また，乾燥収縮ひ ずみ, 中性化深さ, 凍結融解抵抗性についてもスラッジ 水混入による悪影響は認められなかった。なお，本実験 では，凝結調整剤を用いないスラッジ水の利用について は強度増進の程度が若干低い結果となったことから, 注 意を要する。

以上の結果から，スラッジ水に凝結調整剂を適量添加 することで，スラッジ水の品質の安定化が図れ，スラッ ジ固形分率 15\% までの有効利用が可能になったと考元ら れる. 生コンプラントでのゼロエミッションの達成が期 待される。

\section{参考文 献}

1) JIS A 5308 レディーミクストコンクリート 附属書 9.

2 ) 中本純次, 戸川一夫, 三岩敬孝, 材料, 49, 1121 (2000).

$3)$ 中本純次, 戸川一夫, 三岩敬孝, 材料, 50, 812 (2001).

4) 中本純次, 戸川一夫, 三岩敬孝, 材料, 51，1117（2002）.

5 ）日本コンクリート工学協会, コンクリートスラッジの有効 利用に関するシンポジゥム，JCI-C40，第Ｉ編（1996）.

6 ) 中本純次, 戸川一夫, 三岩敬孝, 谷 敏行, セメントコン クリート論文集, No.53, 318 (1999).

7 ）土木学会, コンクリート標準示方書「施工編」付録 I (2002).

8) 中本純次, 戸川一夫, 三岩敬孝, 谷 敏行, セメントコン クリート論文集, No.57，32（2003）. 